\title{
ICDP workshop on the Lake Tanganyika Scientific Drilling Project: a late Miocene-present record of climate, rifting, and ecosystem evolution from the world's oldest tropical lake
}

\author{
James M. Russell ${ }^{1}$, Philip Barker ${ }^{2}$, Andrew Cohen ${ }^{3}$, Sarah Ivory ${ }^{4}$, Ishmael Kimirei ${ }^{5}$, Christine Lane ${ }^{6}$, \\ Melanie Leng ${ }^{7}$, Neema Maganza ${ }^{8}$, Michael McGlue ${ }^{9}$, Emma Msaky $^{8}$, Anders Noren $^{10}$, \\ Lisa Park Boush ${ }^{11}$, Walter Salzburger ${ }^{12}$, Christopher Scholz ${ }^{13}$, Ralph Tiedemann ${ }^{14}$, Shaidu Nuru ${ }^{8,13}$, \\ and the Lake Tanganyika Scientific Drilling Project (TSDP) Consortium ${ }^{+}$ \\ ${ }^{1}$ Department of Earth, Environmental, and Planetary Sciences, Brown University, Providence, RI, USA \\ ${ }^{2}$ Lancaster Environment Centre, Lancaster University, Lancaster, UK \\ ${ }^{3}$ Department of Geosciences, University of Arizona, Tucson, AZ, USA \\ ${ }^{4}$ Department of Geosciences, Penn State University, University Park, PA, USA \\ ${ }^{5}$ Tanzania Fisheries Research Institute, TAFIRI-Kigoma Centre, Kigoma, Tanzania \\ ${ }^{6}$ Department of Geography, Cambridge University, Cambridge, UK \\ ${ }^{7}$ British Geological Survey, Nottingham, UK \\ ${ }^{8}$ Tanzania Petroleum Development Corporation, Dar es Salaam, Tanzania \\ ${ }^{9}$ Department of Earth and Environmental Sciences, University of Kentucky, Lexington, KY, USA \\ ${ }^{10}$ Continental Scientific Drilling Coordination Office, University of Minnesota, Minneapolis, MN, USA \\ ${ }^{11}$ Center of Integrative Geosciences, University of Connecticut, Storrs, CT, USA \\ ${ }^{12}$ Zoological Institute, Department of Environmental Sciences, University of Basel, Basel, Switzerland \\ ${ }^{13}$ Department of Earth Sciences, Syracuse University, Syracuse, NY, USA \\ ${ }^{14}$ Unit of Evolutionary Biology/Systematic Zoology, University of Potsdam, Potsdam, Germany

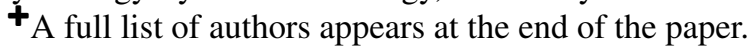

Correspondence: James M. Russell (james_russell@brown.edu)

Received: 27 September 2019 - Revised: 19 January 2020 - Accepted: 28 January 2020 - Published: 27 May 2020

\begin{abstract}
The Neogene and Quaternary are characterized by enormous changes in global climate and environments, including global cooling and the establishment of northern high-latitude glaciers. These changes reshaped global ecosystems, including the emergence of tropical dry forests and savannahs that are found in Africa today, which in turn may have influenced the evolution of humans and their ancestors. However, despite decades of research we lack long, continuous, well-resolved records of tropical climate, ecosystem changes, and surface processes necessary to understand their interactions and influences on evolutionary processes. Lake Tanganyika, Africa, contains the most continuous, long continental climate record from the mid-Miocene ( $\sim 10 \mathrm{Ma})$ to the present anywhere in the tropics and has long been recognized as a top-priority site for scientific drilling. The lake is surrounded by the Miombo woodlands, part of the largest dry tropical biome on Earth. Lake Tanganyika also harbors incredibly diverse endemic biota and an entirely unexplored deep microbial biosphere, and it provides textbook examples of rift segmentation, fault behavior, and associated surface processes. To evaluate the interdisciplinary scientific opportunities that an ICDP drilling program at Lake Tanganyika could offer, more than 70 scientists representing 12 countries and a variety of scientific disciplines met in Dar es Salaam, Tanzania, in June 2019. The team developed key research objectives in basin evolution, source-to-sink sedimentology, organismal evolution, geomicrobiology, paleoclimatology, paleolimnology, terrestrial paleoecology, paleoanthropology, and
\end{abstract}


geochronology to be addressed through scientific drilling on Lake Tanganyika. They also identified drilling targets and strategies, logistical challenges, and education and capacity building programs to be carried out through the project. Participants concluded that a drilling program at Lake Tanganyika would produce the first continuous Miocene-present record from the tropics, transforming our understanding of global environmental change, the environmental context of human origins in Africa, and providing a detailed window into the dynamics, tempo and mode of biological diversification and adaptive radiations.

\section{Introduction}

The Earth has experienced enormous environmental changes during the last 10 million years, including global cooling that culminated in permanent ice in the northern high latitudes, the expansion of $\mathrm{C}_{4}$ grasslands and other dry tropical biomes, and the development of globally synchronized glacial-interglacial cycles (Cerling et al., 1993; Zachos et al., 2001). Our knowledge of these transitions and their global impacts is primarily based on deep-sea drill cores, yet many of these transitions unfolded on land, where they reshaped the continents and influenced organismal evolution and dispersal, including that of our own species. Scientific drilling under the auspices of the International Continental Drilling Program (ICDP) has begun to elucidate the terrestrial environmental changes that accompanied these events (Soreghan and Cohen, 2013), yet we still lack long, continuous, independently dated sedimentary records to document the rates, amplitudes, and dynamics of continental environmental change from the Miocene to the present. This is particularly the case in the tropics, despite their critical role in maintaining Earth's climate and biodiversity.

Lake Tanganyika (LT), East Africa (Fig. 1) is one of the oldest, largest, and deepest lakes on Earth and is a truly unrivaled site for scientific drilling. Its stratigraphy, which spans the Miocene-present, is the most continuous continental record for this time interval known in the tropics (Colman, 1996). Scientific drilling in LT could thus provide a unique, high-resolution record of tropical continental climate in the late Cenozoic. LT is also one of the most biodiverse lakes on Earth (Salzburger et al., 2014, and fills one of the most deeply subsided parts of the East African rift (Ebinger, 1989). Drilling LT offers outstanding opportunities to investigate evolutionary transitions in aquatic and terrestrial organisms and ecosystems, and the geological evolution of a large continental rift system. In the last 6 years we have convened a series of disciplinary workshops that developed a strong consensus that drilling LT will transform our understanding of climatic, evolutionary, and rift processes (Cohen and Salzburger, 2017; McGlue and Scholz, 2016; Russell et al., 2012). To expand on these objectives, and to develop a fully integrated, interdisciplinary scientific drilling program on Lake Tanganyika, we held an ICDP workshop in Dar es Salaam, Tanzania, from 17 to 20 June 2019, attended by more than 70 scientists. Workshop attendees defined the scientific

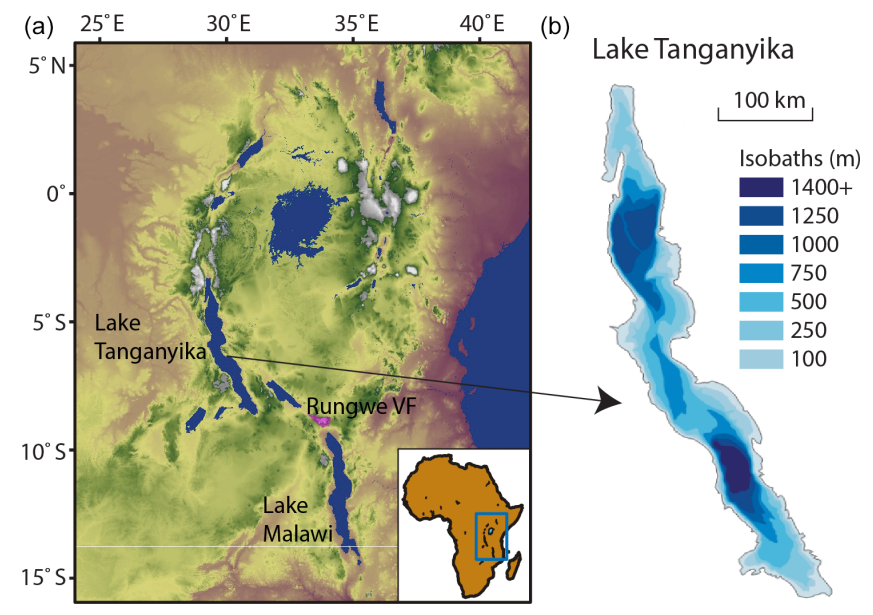

Figure 1. Topographic map of East Africa from SRTM data showing the location of Lake Tanganyika; figure modified from Russell et al. (2012). The lower left inset shows the location of the region within Africa. In panel (b), a bathymetric map of Tanganyika illustrates the major depositional sub-basins within the lake.

rationale, drilling targets and logistics, and other plans for the Lake Tanganyika Scientific Drilling Project (TSDP).

\section{Lake Tanganyika: a world-class site for scientific drilling}

Lake Tanganyika $\left(32600 \mathrm{~km}^{2}, 1470 \mathrm{~m}\right.$ deep, 4-9 $9^{\circ} \mathrm{S}, 29$ $31^{\circ} \mathrm{E}$ ) is near the center of the western branch of the East African Rift on the border between Tanzania, the Democratic Republic of Congo (DRC), Burundi, and Zambia (Fig. 1). Precipitation is strongly seasonal, with a pronounced dry season from June to August when the tropical rain belt shifts northward. During this season, strong southerly winds associated with the East African and Indian monsoons flow over the basin and cause lake upwelling that drives primary production by algae, especially diatoms, forming the basis for a fishery that has yielded up to $\sim 200000 t$ of fish annually (Descy et al., 2005), one of the largest inland fisheries in the world. All of these components of LT vary in response to climate, as documented in intricate detail by geochemical and fossil records in shallow sediment cores (Cohen and Salzburger, 2017; Tierney and Russell, 2007). 


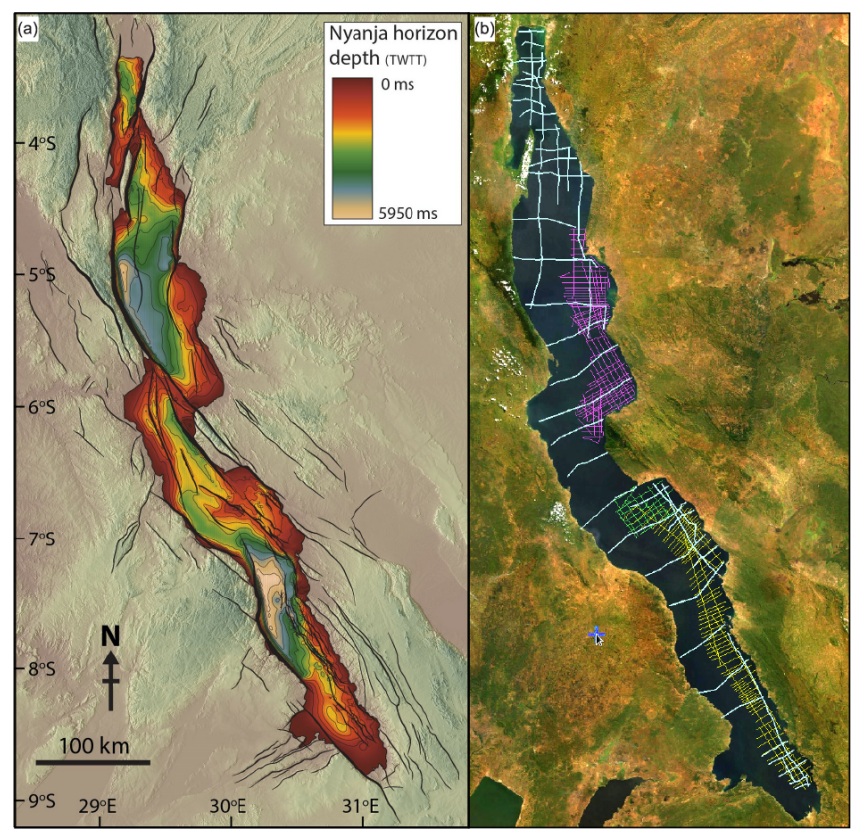

Figure 2. In panel (a), a contour map shows the two-way travel time from lake surface to acoustic basement (i.e., the Nyanja Event) deduced from seismic reflection data shown within a regional digital elevation model based on $90 \mathrm{~m}$ Surface Radar Topography Mission data. Major interpreted faults are shown. In panel (b), a map of seismic lines collected from Lake Tanganyika overlain on a satellite image (ㄷ Esri imagery - source: Esri, i-cubed, USDA, USGS, AEX, GeoEye, Getmapping, Aerogrid, IGN, IGP, UPREGP, and the GIS). Light blue lines are 24-fold multichannel seismic lines collected by Project PROBE 1993-1984. Green lines are single-channel sparker profiles collected during the Nyanza Project (McGlue et al., 2008). Yellow profiles are 60-fold data acquired in 2012 as part of a commercial exploration program. Magenta lines are single-channel high-resolution air-gun profiles collected in 1997.

Lake Tanganyika is part of East Africa's western rift (Rosendahl, 1987; Ebinger, 1989). Extension is accommodated by steeply dipping border faults that commonly form the coastlines of the lake (Fig. 2). Nine border faults link together to form the Lake Tanganyika rift, producing several sub-basins with water depths of $1000 \mathrm{~m}$ or more separated by deep-water horsts (Scholz and Rosendahl, 1988). The Rungwe Volcanic Province (RVP) lies $\sim 250 \mathrm{~km}$ south of LT. RVP volcanism has been ongoing since at least $9 \mathrm{Ma}$ and is dominated by effusive and explosive eruptions, with the oldest pyroclastic units dated to $\sim 8.6 \mathrm{Ma}$ (Fontijn et al., 2012). Several volcanic ash beds derived from the RVP have been found in shallow cores from southern LT (e.g., Livingstone, 1965), suggesting great potential for tephra-based age control in our project.

Several thousand kilometers of reflection seismic data have been acquired on Lake Tanganyika (McGlue et al., 2008; Muirhead et al., 2019; Rosendahl, 1988; Scholz et al., 2003), including a commercial survey of the southeastern part of the Tanzanian side of the lake completed in 2012 (Fig. 2). LT's seismic stratigraphic section is comprised of a set of four major depositional sequences (Fig. 3) that overlie a set of reflections referred to as the "Nyanja Event", which is interpreted to mark the onset of the current phase of rifting and the initiation of the present-day LT (Rosendahl, 1988). Its Cenozoic sedimentary succession has been divided into six sequences (Muirhead et al., 2019) that vary widely in thickness across the basin. These sequences include the following:

- Sequence S1, characterized by low-amplitude, discontinuous reflections. The relatively uniform thickness and character of this sequence implies low-relief, shallow lacustrine and fluvial environments formed during the earliest phase of the formation of LT.

- Sequence S2, which consists of high-frequency reflectors and thickens westward, indicating subsidence of the western border fault. Zones of high continuity extend over tens of kilometers, implying that a deep rift lake was in place by this time.

- Sequences S3-S5 are characterized by alternating highand low-amplitude reflectors, often with incised channels and paleodeltaic deposits. This suggests varying lake levels, probably caused by Plio-Pleistocene climatic changes, with water-level changes of up to $600 \mathrm{~m}$.

- Sequence S6, characterized by low-amplitude but highfrequency, high-continuity sediments. The character, lateral extent, and external draping form are all similar to fine-grained hemipelagic muds drilled in nearby Lake Malawi (Scholz et al., 2011).

Most core-based research at LT has focused on the last glacial cycle to the present, as only short piston cores ( $\sim 10 \mathrm{~m}$ or less from within S6) are available. Sedimentological data documented a lake lowstand of $\sim 200 \mathrm{~m}$ during the Last Glacial Maximum (McGlue et al., 2008), when temperatures $\sim 3{ }^{\circ} \mathrm{C}$ cooler than present allowed Afromontane forests to expand around the lake (Ivory and Russell, 2016). Following these cold, dry conditions, climate rebounded during the Pleistocene-Holocene transition, marked by a very warm, wet early-Holocene interval known as the "African Humid Period" (Tierney et al., 2008). These events occurred throughout much of equatorial and northern Africa (OttoBliesner et al., 2014), highlighting LT's potential as a "master record" of African environmental history. Organic geochemical analyses of short cores have shown that the lake has warmed by $1-2{ }^{\circ} \mathrm{C}$ in the last century in response to anthropogenic greenhouse gas forcing, resulting in significant reductions in nutrient upwelling, primary productivity, mollusks, and fish (Cohen et al., 2016). These results highlight the potential of an LT drill core to provide quantitative estimates of tropical climate, to record climate variations, and to 

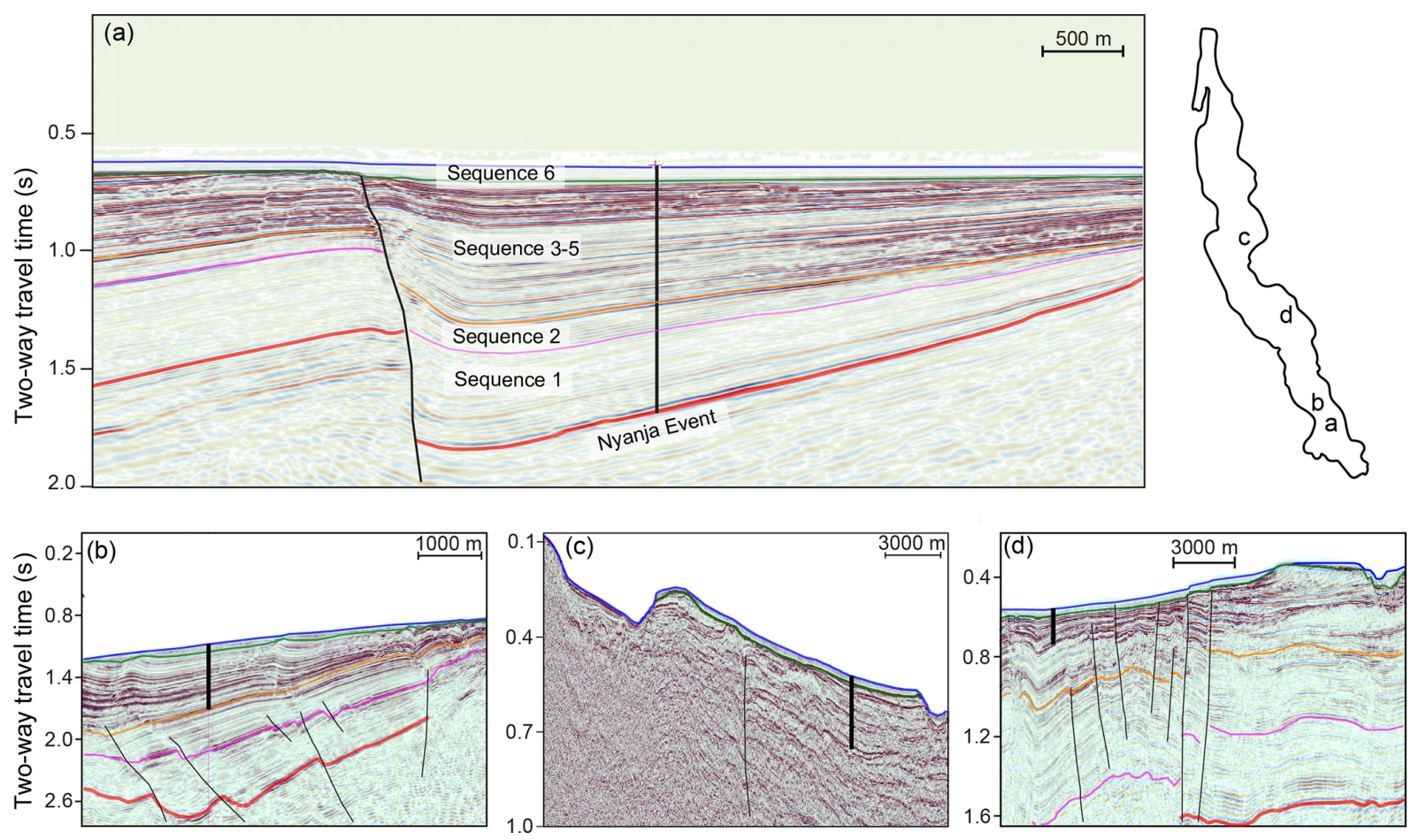

Figure 3. Seismic reflection profiles showing potential drilling sites at Lake Tanganyika. Panel (a) illustrates a potential drilling site that captures the major seismic sequences (S1-S6) present in the lake. Sequences S3-S5 are condensed and likely truncated by erosion at this site, but these sequences can be drilled at a nearby site in deeper water (b). Panels (c) and (d) illustrate sections in shallower water where fossiliferous sediments can be drilled for evolutionary biological studies. In all panels, black lines indicate potential drill holes, blue lines trace the lake floor; red lines indicate the Nyanja event (the interpreted base of the modern rift); and pink, orange, and green lines trace the boundaries between sequences 1 and 2, 2 and 3, and 5 and 6, respectively.

record the response of equatorial climate to global forcings and processes.

\section{Workshop structure and findings}

We convened a workshop to define scientific priorities and analyses, logistics, drilling targets, and education and outreach plans for a deep scientific drilling project in Lake Tanganyika. Presentations on the first day focused on the limnology of Lake Tanganyika and the evolutionary history of its biota, the structural geology of the East African and Tanganyikan rifts, the sedimentary architecture of LT, and the environmental history of East Africa. Participants then spent the next three days in breakout groups to develop scientific hypotheses and strategies in the broad areas of paleoclimatology, basin evolution, source-to-sink sedimentology, organismal evolution, paleolimnology, terrestrial paleoecology, paleoanthropology, geomicrobiology, and geochronology. These scientific breakout discussions led to prioritized research goals within each group linked to drilling targets, from which we developed a coordinated, parsimonious drilling plan.

Sub-Saharan Africa is highly socioeconomically vulnerable to future climate change. However, considerable uncer- tainty remains in climate predictions for the continent (Niang et al., 2014), demanding that we test climate model simulations against reconstructions of climate under higher greenhouse gas concentrations than the present. The MiocenePliocene presents the best analog for future climate, as continental configurations were similar to the present yet greenhouse gas concentrations were higher than present (Haywood et al., 2016; Zhang et al., 2013). Shallow cores from LT have provided outstanding records of late Quaternary to recent changes in climate (Cohen et al., 2016; Tierney et al., 2008) and benchmark targets for late-Pleistocene paleoclimate modeling (Otto-Bliesner et al., 2014), highlighting the lake's potential to establish a tropical paleoclimate reference section for the late Neogene. Thus, LT offers an unmatched opportunity to evaluate the response of tropical rainfall and temperature to changes in high-latitude glaciation, greenhouse gas concentrations, insolation forcing, and other changes in global climate boundary conditions during the last $\sim 10$ million years. The occurrence of severe hydroclimate fluctuations and lake level draw-downs over the past $200 \mathrm{kyr}$ in the Malawi Rift are well-documented (Scholz et al., 2011), and other extant lakes in Africa, including LT (Burnett et al., 2011), show evidence of similar variability. Drilling in LT is critical for determining the phasing of this high-amplitude 
variability across the African tropics. Moreover, TSDP will represent the culmination of several decades of scientific drilling and coring in East African lakes and paleolakes. ICDP records from Lake Malawi, the Hominin Sites and $\mathrm{Pa}-$ leolakes Drilling Project (HSPDP), and Lake Challa have provided considerable insight into East African climate but continuously span only the last $\sim 1.2 \mathrm{Myr}$ at Lake Malawi (Ivory et al., 2016), with more discontinuous HSPDP records back to 3.3 Ma (Campisano et al., 2017). A long, continuous record from LT will therefore provide a master stratigraphy from the region to contextualize the Lake Malawi, HSPDP, and Lake Challa records within late Miocene-present environmental change.

The western branch of the East African rift is the global archetype of an active, amagmatic early-stage rift, and its thick sediments preserve a multimillion-year record of extensional tectonics and landscape evolution. The western branch of the rift experiences the largest magnitude earthquakes of the African continent, and presents textbook examples of rift segmentation and fault behavior (Lavayssière et al., 2019). This deep, anoxic, freshwater body is also commonly cited as a classic example of a continental basin accumulating lacustrine petroleum source rocks (Katz, 1996), yet stratigraphic prediction in ancient low-latitude rift basins has been a major challenge. TSDP will provide opportunities to investigate (1) how along-strike basin segmentation and fault growth impact sedimentation and source-to-sink processes; (2) the dynamics of fault slip, propagation and linkage, and whether they conform to rifting models; (3) the history of magmatic activity and geothermal gradients and how they relate to basin evolution in a "cold rift"; and (4) how these processes influence Tanganyika's limnological and biological evolution, stratigraphy, and resources.

Understanding how ecosystems are assembled and altered through time, and how speciation, dispersal, and extinction shape species assemblages and communities has been a fundamental problem in ecology and evolutionary biology ever since Darwin. LT harbors spectacular endemic faunas, with hundreds of unique species of fish, in particular cichlids, as well as mollusks, and crustaceans that have evolved over the lake's long history (Salzburger et al., 2014). These endemic species form unique communities in benthic and pelagic habitats, and many of these organisms have left fossil records in LT's sediments (e.g., Cohen et al., 2016). Together with ancient DNA (aDNA) analyses these fossils will provide records of the evolution, radiation, and extinction of endemic taxa and coevolved ecosystems. The combination of LT's antiquity and size probably accounts for its extraordinary diversity, but the role of limnological, climatic, and tectonic changes in shaping LT's flora and fauna remain largely hypothetical. The availability of a continuous paleolimnological record of the lake together with fossil and, in the younger intervals, aDNA records of the lake's endemic organisms would allow us for the first time to understand the rates, dynamics, and drivers of adaptive radiation - a truly transformative advance for evolutionary biology.

Lake Tanganyika is surrounded by Miombo woodlands, part of the largest dry forest tropical biome on Earth. It is generally assumed that these ecosystems arose at the expense of the Guineo-Congolian rainforests to the west, but there is little evidence to support this hypothesis. Palynological records from LT have highlighted the sensitivity of Miombo and other surrounding ecosystems to climate and environmental changes, including human impacts (Ivory and Russell, 2016). Our understanding of the processes that generated the present-day structure of these ecosystems would be greatly enhanced by records spanning the larger range of climate variations occurring from the Miocene to the present. Moreover, Africa has a long history of hominin-environmental interactions. A Miocene-present record from LT will provide a benchmark record of the environmental context in which our ancestors lived and evolved.

While Lake Tanganyika is renowned for its aquatic biodiversity, its microbial diversity in the water column and sediments remain largely unknown. Drill cores will allow us to explore LT's deep biosphere, the role it plays in the lake's carbon, nitrogen, sulfur, and other elemental cycles, and how the water column and sedimentary microbial communities vary in relation to climatic and tectonic changes. Changes in the microbial community, acting in concert with limnological processes and climatically and tectonically driven changes in the lake's physical structure, should govern key aspects of the lake ecosystem, including primary productivity, and ultimately its biodiversity.

Investigations of Lake Tanganyika's depositional history will require a robust geochronology. Participants reviewed state-of-the-art geochronological techniques and their applicability to LT sediments. In addition to the Rungwe Volcanic Province (RVP) in southern Tanzania, significant NeogeneQuaternary volcanic events in the Central Kenyan Rift, northern Tanzania and the Virunga Volcanic Province could have transported ash to the LT basin. RVP-derived tephra are relatively rich in potassium (Fontijn et al., 2012), and several are known to be present in Holocene-age sediments from southern LT (e.g., Livingstone, 1965). Ar-Ar ages from RVP tephra in the lake core, or from coarser correlative proximal outcrops, will provide multiple anchor points for our core chronology, and this opportunity guides us to concentrate our drilling efforts in LT's southern basin. Ar-Ar, together with ${ }^{14} \mathrm{C}$, luminescence dating, paleomagnetic, and other dating techniques, will provide vital independent age estimates for the LT core chronology, as well as contributing to future regional geochronologic and earth system studies. This effort will provide a new eastern African palaeomagnetic reference curve back to the Miocene and a stratified multi-million-year record of explosive volcanism from the southern East African rift volcanic provinces.

Ultimately our goal is to integrate information from these different fields to understand the coupled climatic, geologic, 
and biological processes that control the evolution of Africa's largest rift lake. Participants discussed possible drilling targets and strategies to address these issues, and the need for continuity, resolution, and lithologies through the different sedimentary units (sequences S1-S6) to address the goals outlined above. Participants emphasized the importance of determining LT's age and early conditions, and the transformative nature of a Miocene-present paleoclimate record from the tropics. Subsidence and sedimentation rate estimates suggest the Nyanja Event occurred between 9 and $12 \mathrm{Ma}$ (Cohen et al., 1993). Accordingly, sequences S1 and S2 could date to the Miocene and Pliocene, and S3-S6 to the Pleistocene and Holocene. Thus, the team agreed on the importance of obtaining a complete representative section from the lake - i.e., a record extending to the Nyanja Event. Participants also highlighted the importance of obtaining fine-grained, continuous sediments for state-of-the-art paleoenvironmental analyses and for essential geochronologic control. It is prohibitively expensive to drill $2-3 \mathrm{~km}$ holes from LT's deep basins, where sedimentation rates are rapid $\left(0.5 \mathrm{~m} \mathrm{kyr}^{-1}\right.$ or more). However, our team has identified hemipelagic sections that include all of the major sedimentary units in LT, in water depths below the maximum depth of lake lowstands and with combined water and sediment depths of $\sim 1500 \mathrm{~m}$ (Fig. 3), achievable with intermediatescale drilling technology.

Based on these needs, we anticipate an offset drilling program at two sites in southern Lake Tanganyika, proximal to the Rungwe volcanoes and where we have excellent seismic stratigraphic constraints. Two offset holes drilled to $\sim 1500 \mathrm{~m}$ depth (combined water and sediment) will allow recovery of a relatively complete Miocene-present record (Fig. 3a and b). A shallow $(\sim 100 \mathrm{~m})$ hole at one of these sites will provide sediment for geomicrobiological investigations across the strong biogeochemical gradients that should exist in the uppermost sediment column. We anticipate also recovering a set of shallow holes in central LT to evaluate evolutionary and paleolimnological gradients during lake level lowstands that might bifurcate LT into multiple basins (Fig. 3c and d). We are now pursuing pre-drilling logistical and scientific activities including the assembly of a Tanganyika database to improve access to information about the lake, drilling platform design, safety evaluations and project permitting, methodological tests using existing sediment cores, and educational and outreach activities within the riparian countries.

Data availability. No data sets were used in this article.

Team list. Christian Albrecht (University of Giessen, Germany), Rahma Ali (Petroleum Upstream Regulatory Authority, Tanzania), Ramon Arrowsmith (Arizona State University, USA), Danstan Asanga (Petroleum Upstream Regulatory Author- ity, Tanzania), Yemane Asmerom (University of New Mexico, USA), Charles Bakundukize (University of Burundi, Burundi), Philip Barker (Lancaster University, UK), Thorsten Bauersachs (University of Kiel, Germany), Catherine Beck (Hamilton College, USA), Melissa Berke (University of Notre Dame, USA), Emily Beverley (University of Houston, USA), Martin Blaauw (Queen's University, UK), Lisa Boush (University of Connecticut, USA), Erik Brown (University of Minnesota Duluth, USA), Chris Campisano (Arizona State University, USA), Barbara Carrapa (University of Arizona, USA), Isla Castaûeda (University of Massachusetts, USA), Andy Cohen (University of Arizona, USA), Sylvia Dee (Rice University, USA), Alan Deino (Berkeley Geochronology Center, USA), Cindy Ebinger (Tulane University, USA), Geoff Ellis (US Geological Survey, USA), Verena Foerster (University of Cologne, Germany), Karen Fontijn (University of Brussels, Belgium), George Gehrels (University of Arizona, USA), Adrian Indemaur (University of Basel, Switzerland), Sarah Ivory (Penn State University, USA), Elena Jovanovska (Justus Liebig University, Germany), Annett Junginger (University of Tübingen, Germany), Stefanie Kaboth (Potsdam University, Germany), Jens Kallmeyer (Geoforschungszentrum, Germany), Ishmael Kimirei (Tanzania Fisheries Institute, Tanzania), John King (University of Rhode Island, USA), Bronwen Konecky (Washington University, USA), Christine Lane (Cambridge University, UK), Melanie Leng (British Geological Survey, UK), Neema Maganza (Tanzania Petroleum Development Corporation, Tanzania), Darren Mark (SUERC, UK), Mike McGlue (University of Kentucky, USA), Pete McIntyre (University of Wisconsin, USA), Ellinor Michel (Natural History Museum, UK), Doreen Mkuu (Tanzania Petroleum Development Corporation, Tanzania), Leah Morgan (US Geological Survey, USA), Emma Msaky (Tanzania Petroleum Development Corporation, Tanzania), Cassy Mtetela (University of Dar es Salaam, Tanzania), Nshombo Muderwha (Hydrobiology Laboratory, Uvira, Congo), James Muirhead (Syracuse University, USA), Cassian Mumbi (Tanzania Wildlife Research Institute, Tanzania), Mo Muschick (University of Bern, Switzerland), David Nahimana (University of Burundi, Burundi), Venosa Ngowi (Tanzania Petroleum Development Corporation, Tanzania), Pashcal Njiko (Tanzania Petroleum Development Corporation, Tanzania), Simon Nkenyeli (Petroleum Upstream Regulatory Authority, Tanzania), Hudson Nkotagu (University of Dar es Salaam, Tanzania), Anders Noren (University of Minnesota, CSDCO, USA), Gaspard Ntakimazi (University of Burundi, Burundi), Shaidu Nuru (Tanzania Petroleum Development Corporation, Tanzania), Davide Oppo (University of Louisiana, USA), Lotta Purkamo (Geological Survey of Finland, Finland), Jessica Rick (University of Wyoming, USA), Helen Roberts (Aberystwyth University, UK), Fabrizia Ronco (University of Basel, Switzerland), James Russell (Brown University, USA), Walter Salzburger (University of Basel, Switzerland), Charles Sangweni (Petroleum Upstream Regulatory Authority, Tanzania), Chris Scholz (Syracuse University, USA), Yohana Shaghude (University of Dar es Salaam, Tanzania), Josephat Shigela (Tanzania Petroleum Development Corporation, Tanzania), Donna Shillington (Lamont Doherty Earth Observatory, USA), Chen Shuang Sophia (Nanjing Institute of Geography and Limnology, China), Mark Sier (CNIEH, Spain), Mike Soreghan (University of Oklahoma, USA), Trisha Spanbauer (University of Texas, Austin, USA), Charlotte Spencer-Jones (Durham University, UK), Richard Staff (Glasgow University, SUERC, UK), 
Jeffery Stone (Indiana State University, USA), Ralph Tiedemann (Potsdam University, Germany), Jonathan Todd (Natural History Museum, UK), Martin Trauth (Potsdam University, Germany), Bert van Bocxlaer (University of Lille, France), Finn Viehberg (University of Cologne, Germany), Hendrik Vogel (University of Bern, Switzerland), Hubert Vonhof (Max Planck Institute, Germany), Chris Wolff (Lancaster University, UK), Qinglong Wu (Nanjing Inst. Limnology, China), Chad Yost (University of Arizona, USA), Christian Zeeden (Leibniz Institute of Applied Geophysics, Germany).

Author contributions. JMR organized the workshop and wrote the paper. PB, AC, SI, IK, CL, ML, NM, MM, EM, AN, LPB, WS, CS, RT, and SN all contributed to the workshop and co-wrote the paper. The TSDP Consortium provided intellectual input to the paper and workshop.

Competing interests. The authors declare that they have no conflict of interest.

Acknowledgements. We would like to thank the ICDP, the University of Basel, Brown University, and the EarthRates Program for funding the workshop. We would also like to thank the Petroleum Upstream Regulatory Authority, the Tanzanian Fisheries Research Institute, the Tanzania Petroleum Development Corporation, and the University of Dar es Salaam for their assistance in hosting the workshop in Dar es Salaam.

Financial support. This research has been supported by the International Continental Drilling Program (grant no. 1-2018).

Review statement. This paper was edited by Ulrich Harms and reviewed by Julie Brigham-Grette and two anonymous referees.

\section{References}

Burnett, A. P., Soreghan, M. J., Scholz, C. A., and Brown, E. T.: Tropical East African climate change and its relation to global climate: a record from Lake Tanganyika, tropical East Africa, over the past 90+ kyr, Palaeogeogr. Palaeocl., 303, 155-167, 2011.

Campisano, C. J., Cohen, A. S., Arrowsmith, J. R., Asrat, A., Behrensmeyer, A. K., Brown, E. T., Deocampo, D. M., Deino, A. L., Feibel, C. S., Kingston, J. D., Lamb, H. F., Lowenstein, T. K., Noren, A., Olago, D. O., Owen, R. B., Pelletier, J. D., Potts, R., Reid, K. E., Renaut, R. W., Russell, J. M., Russell, J. L., Schabitz, F., Stone, J. F., Trauth, M. H., and Wynn, J. G.: The Hominin Sites and Paleolakes Drilling Project: high-resolution paleoclimate records from the East African rift system and their implications for understanding human evolution, Paleoanthropology, $1-43,2017$.
Cerling, T. E., Wang, Y., and Quade, J.: Expansion of $\mathrm{C}_{4}$ ecosystems as an indicator of global ecological change in the late Miocene, Nature, 361, 344-345, 1993.

Cohen, A. S. and Salzburger, W.: Scientific Drilling at Lake Tanganyika, Africa: A Transformative Record for Understanding Evolution in Isolation and the Biological History of the African Continent, University of Basel, 6-8 June 2016, Sci. Dril., 22, 4348, https://doi.org/10.5194/sd-22-43-2017, 2017.

Cohen, A. S., Soreghan, M., and Scholz, C.: Estimating the age of formation of lakes: an example from Lake Tanganyika, East African rift system, Geology. 21, 511-514, 1993.

Cohen, A. S., Gergurich, E. L., Kraemer, B. M., McGlue, M., McIntyre, P. B., Russell, J. M., Simmons, J. D., nd Swarzenski, P. W.: Climate warming reduces fish production and benthic habitat in Lake Tanganyika, one of the most biodiverse freshwater ecosystems, P. Nat. Acad. Sci. USA, 113, 9563-9568, 2016.

Colman, S.: Continental drilling for paleoclimatic records, recommendations from an international workshop, IGBP-PAGES, Bern, Switzerland, 104 pp., 1996.

Descy, J. P., Plisnier, P. D., Leporcq, B., Stenuite, S., Pirlot, S., Stimart, J., Gosselain, V., Andre, L., Alleman, L., Langlet, D., Vyverman, W., Cocquyt, C., De Wever, A., Stoyneva, M. P., Deleersnijder, E., Naithani, J., Chitamwebwa, D., Chande, A., Kimirei, I., Sekadende, B., Mwaitega, S., Muhoza, S., Sinyenza, D., Makasa, L., Lukwessa, C., Zulu, I., and Phiri, H.: Climlake: Climate variability as recorded in Lake Tanganyika. Final Report (2001-2005), in: FSPO - Global Change, ecosystems, and biodiversity, edited by: Plisnier, P. D. and Descy, J. P., Brussels, Belgium, 104 pp., 2005.

Ebinger, C. J.: Tectonic development of the western branch of the East African rift valley, Geol. Soc. Amer. Bull., 101, 117-133, 1989.

Fontijn, K., Williamson, D., Mbede, E., and Ernst, G. G. J.: The Rungwe Volcanic Province - A volcanological Review, J. Afr. Earth Sci., 63, 12-31, 2012.

Haywood, A. M., Dowsett, H. J., Dolan, A. M., Rowley, D., Abe-Ouchi, A., Otto-Bliesner, B., Chandler, M. A., Hunter, S. J., Lunt, D. J., Pound, M., and Salzmann, U.: The Pliocene Model Intercomparison Project (PlioMIP) Phase 2: scientific objectives and experimental design, Clim. Past, 12, 663-675, https://doi.org/10.5194/cp-12-663-2016, 2016.

Ivory, S. J. and Russell, J. M.: Climate, herbivory, and fire controls on tropical African forest for the last $60 \mathrm{ka}$, Quaternary Sci. Rev., 148, 101-114, 2016.

Ivory, S. J., Blome, M. W., King, J. W., McGlue, M., Cole, J. E., and Cohen, A. S.: Environmental change explains cichlid adaptive radiation at Lake Malawi over the past 1.2 million years, P. Nat. Acad. Sci. USA, 113, 11895-11900, 2016.

Katz, B. (Ed.): Controls on the distribution of lacustrine source rocks through time and space, in: Lacustrine Basin Exploration: Case Studies and Modern Analogs, The American Association of Petroleum Geologists, Tulsa, USA, 61-76, 1996.

Lavayssière, A., Drooff, C., Ebinger, C. J., Gallacher, R., IllsleyKemp, F., O'liva, S. J., and Keir, D.: Depth extent and kinematics of faulting in the southern Tanganyika rift, Africa, Tectonics, 38, 842-862, 2019.

Livingstone, D. A.: Sedimentation and the history of water level change in Lake Tanganyika, Limnol. Oceanogr., 10, 607-610, 1965. 
McGlue, M. and Scholz, C.: Source to Sink Processes in Lake Tanganyika: A STEPPE Workshop Report, STEPPE Workshop Reports, 10-11 December 2016, Boulder, CO, USA, 2016.

McGlue, M. M., Lezzar, K. E., Cohen, A. S., Russell, J. M., Tiercelin, J. J., Felton, A., Mbede, E., and Nkotagu, H.: Seismic records of late Pleistocene aridity in Lake Tanganyika, tropical East Africa, J. Paleolimnol., 40, 635-653, 2008.

Muirhead, J. D., Wright, L. J. M., and Scholz, C.: Rift evolution in regions of low magma input in East Africa, Earth Planet. Sc. Lett., 506, 332-346, 2019.

Niang, I., Ruppel, O. C., Abdrabo, M. A., Essel, A., Lennard, C., Padgham, J., and Urquahart, P.: Africa, in: Climate Change 2014: Impacts, Adaptation, and Vulnerability. Part B: Regional Aspects, Contribution of Working Group II to the Fifth Assessment Report of the Intergovernmental Panel on Climate Change, edited by: Barros, V. R., Field, C. B., Dokken, D. J., Mastrandrea, M. D., Mach, K. J., Bilir, T. E., Chatterjee, M., Ebi, K. L., Estrada, Y. O., Genova, R. C., Girma, B., Kissel, E. S., Levy, A. N., MacCracken, S., Mastrandrea, P. R., and White, L. L., Cambridge University Press, Cambridge, UK, 1199-1265, 2014.

Otto-Bliesner, B. L., Russell, J. M., Clark, P. U., Liu, Z., Overpeck, J. T., Konecky, B. L., DeMenocal, P., Nicholson, S. E., He, F., and Lu, Z.: Coherent changes of southeastern equatorial and northern African rainfall during the last deglaciation, Science, 346, 1223 1227, 2014.

Rosendahl, B. R.: Architecture of continental rifts with special reference to east Africa, Annu. Rev. Earth Pl. Sc., 15, 445-503, 1987.

Rosendahl, B. R.: Seismic atlas of Lake Tanganyika, Project PROBE Geophysical Atlas Series, Duke University, Durham, NC, USA, 1988.

Russell, J. M., Cohen, A. S., Johnson, T. C., and Scholz, C. A.: Scientific Drilling in the East African Rift Lakes: A Strategic Planning Workshop, Sci. Dril., 14, 49-54, https://doi.org/10.2204/iodp.sd.14.08.2012, 2012.
Salzburger, W., van Bocxlaer, B., and Cohen, A. S.: Ecology and evolution of the African Great Lakes and their faunas, Annu. Rev. Ecol. Evol. S., 45, 519-545, 2014.

Scholz, C. and Rosendhal, B. R.: Low lake stands in Lakes Malawi and Tanganyika, East Africa, delineated with multifold seismic data, Science, 240, 1645-1648, 1988.

Scholz, C., King, J. W., Ellis, G. S., Swart, P. K., Stager, J. C., and Colman, S. M.: Paleolimnology of Lake Tanganyika, East Africa, over the past $100 \mathrm{kyr}$, J. Paleolimnol., 30, 139-150, 2003.

Scholz, C., Cohen, A. S., Johnson, T. C., King, J. W., Talbot, M. R., and Brown, E. T.: Scientific drilling in the Great Rift Valley: the 2005 Lake Malawi Drilling Project - an overview of the past 145000 years of climate variability in Southern Hemisphere East Africa, Palaeogeogr. Palaeocl., 303, 3-19, 2011.

Soreghan, G. S. and Cohen, A. S.: Scientific drilling and the evolution of the earth system: climate, biota, biogeochemistry and extreme systems, Sci. Dril., 16, 63-72, https://doi.org/10.5194/sd16-63-2013, 2013.

Tierney, J. and Russell, J. M.: Abrupt climate change in southeast tropical Africa influenced by Indian monsoon variability and ITCZ migration, Geophys. Res. Lett., 34, L15709, https://doi.org/10.1029/2007GL029508, 2007.

Tierney, J. E., Russell, J. M., Huang, Y., Sinninghe-Damste, J. S., Hopmans, E. C., and Cohen, A. S.: Northern hemisphere controls on tropical southeast African climate during the last 60000 years, Science, 332, 252-255, 2008.

Zachos, J., Pagani, M., Sloan, L., Thomas, E., and Billups, K.: Trends, Rhythms, and Aberrations in Global Climate $65 \mathrm{Ma}$ to Present, Science, 292, 686-693, 2001.

Zhang, Y. G., Liu, Z., Bohaty, S. M., and DeConto, R.: A 40million-year history of atmospheric $\mathrm{CO}_{2}$, Philos. T. Roy. Soc. A, 371, 20130096, https://doi.org/10.1098/rsta.2013.0096, 2013. 